\title{
ORIGINAL ARTICLE \\ Mung bean proteins and peptides: nutritional, functional and bioactive properties
}

\author{
ZhuYi-Shen"*, Sun Shuai', Richard FitzGerald² \\ 'College of Biotechnology and Pharmaceutical Engineering, Nanjing Tech University, Nanjing, China; ${ }^{2}$ Life Science \\ Department, University of Limerick, Limerick, Ireland
}

\begin{abstract}
To date, no extensive literature review exists regarding potential uses of mung bean proteins and peptides. As mung bean has long been widely used as a food source, early studies evaluated mung bean nutritional value against the Food and Agriculture Organization of the United Nations (FAO)/the World Health Organization (WHO) amino acids dietary recommendations. The comparison demonstrated mung bean to be a good protein source, except for deficiencies in sulphur-containing amino acids, methionine and cysteine. Methionine and cysteine residues have been introduced into the $8 \mathrm{~S}$ globulin through protein engineering technology. Subsequently, purified mung bean proteins and peptides have facilitated the study of their structural and functional properties. Two main types of extraction methods have been reported for isolation of proteins and peptides from mung bean flours, permitting sequencing of major proteins present in mung bean, including albumins and globulins (notably 8S globulin). However, the sequence for albumin deposited in the UniProt database differs from other sequences reported in the literature. Meanwhile, a limited number of reports have revealed other useful bioactivities for proteins and hydrolysed peptides, including angiotensin-converting enzyme inhibitory activity, anti-fungal activity and trypsin inhibitory activity. Consequently, several mung bean hydrolysed peptides have served as effective food additives to prevent proteolysis during storage. Ultimately, further research will reveal other nutritional, functional and bioactive properties of mung bean for uses in diverse applications.
\end{abstract}

Keywords: nutrition; protein extraction; functionality; globulins; angiotensin converting enzyme inhibitory activity; trypsin inhibitory activity; anti-fungal activity

Received: 27 October 20 I7; Revised: 20 December 20 I7; Accepted: 19 January 20।8; Published: I 5 February 2018

$\mathrm{M}$ any health organisations worldwide have recommended increased intake of plant-based foods to improve the prevention of chronic diseases and to improve overall human health. As a result, a variety of plant-based functional foods have been introduced into health care programmes (1). One such crop that has exhibited health benefits is mung bean [Vigna radiata (L.)], which is a summer pulse crop with a short growth cycle (70-90 days). It is a widely cultivated plant in many Asian countries as well as in dry regions of southern Europe and warmer parts of Canada and the United States. As an important plant-derived food resource (1), mung bean (2) is well known for its detoxification bioactivities. In addition, it has been used for treating numerous other conditions ranging from enhancement of human mental function to alleviation of heat stroke (3). The overall nutritional properties of mung beans have been recently reviewed by Dahiya et al. (4). Due to its high nutritional value, (5) especially in seeds, mung bean has served as an important food/feed source for humans and animals. Mung bean seeds contain about 20.97-31.32\% protein (6), compared to $18-22 \%$ (7) and $20-30 \%$ (8) for the protein content in soy and kidney beans, respectively. Moreover, protein content of mung bean seeds is about twofold higher than in the cereal seed maize, with a lower storage protein content ( 7 to $10 \%$ ) (9) and significantly higher protein content than observed for conventional root crops (10).

Although high levels of proteins and amino acids in mung beans (11) are believed to be the main contributors to its nutritional content, a low methionine content and the presence of trypsin inhibitor (12) in mung bean seed are thought to be responsible for its low protein efficiency ratio (PER). Meanwhile, mung bean proteins and peptides have also been reported to possess angiotensinconverting enzyme (ACE) inhibitory activity, as well as 
anti-fungal and/or antibacterial activities (3). Although major past use of mung bean seeds has been as a food resource, more recently mung bean extracts, especially protein and peptide isolates, have gained increasing attention for additional diverse applications.

\section{Nutritional properties of the mung bean proteins}

As mentioned above, mung bean seeds are particularly rich in protein, containing about $20.97-31.32 \%$ protein content (6). Mubarak (13) reported a chemical score of $76 \%$ for mung bean amino acids, which was calculated based on the Food and Agriculture Organisation of the United Nations (FAO)/the World Health Organisation (WHO) (14) guidelines. Therefore, due to its high protein content and digestibility, consumption of mung bean seeds in combination with cereals has been recommended to significantly increase the quality of protein intake as part of a vegetarian diet (3). To characterise this nutritional content more specifically, Kudre et al. (10) analysed the protein composition of isolates from mung bean seeds. The total protein content in mung bean protein isolates (MBPI) was $87.8 \%$, with a total amino acid content of $800.2 \mathrm{mg} \mathrm{g}^{-1}$ (Table 1). Essential amino acids constituted $43.5 \%$ of total amino acids in MBPI, whereas sulphurcontaining amino acids constituted approximately $1.6 \%$ of total MBPI amino acids.

Specifically, the essential amino acids such as leucine, lysine and phenylalanine/tyrosine were predominant, followed by valine, isoleucine and histidine (Table 1). In addition, the aromatic amino acid content of MBPI was $12.1 \%$, in which phenylalanine and tyrosine constitutes $11.3 \%$ (90.3 of $\left.800.2 \mathrm{mg} \mathrm{g}^{-1}\right)$. Indeed, the total essential amino acid content of MBPI exceeds the FAO/WHO recommendations (15). Conversely, values for threonine, tryptophan and total sulphur-containing amino acids (methionine and cysteine) were nutritionally inadequate (Table 1).

The protein content of mung bean has been reported to be negatively correlated with the content of lysine and threonine (4), whereas the latter has been positively correlated with methionine content. These results suggest that increase in methionine content is accompanied by decreased total protein content in mung bean. Therefore, the reverse scenario of high protein content in mung bean seed probably reflects low methionine content $(16,17)$. In addition, low levels of threonine, tryptophan and sulphur-containing amino acids (methionine and cysteine), compared to the FAO/WHO recommended values (Table 1), were reported in MBPI. However, Khalil (18) reported that the threonine content was $140.88 \%$ of the value provided by the FAO/WHO, as compared to $83.53 \%$ reported by Kudre et al. (10).

Although mung bean seeds are rich in protein, the deficiency in the sulphur-containing amino acids (methionine and cysteine) places the nutritional quality of mung bean seeds on par with other legumes (19). To address

Table 1. Amino acids in mung bean protein isolates with levels comparing the ones adapted from FAO/WHO (15) guidelines: (10)]

\begin{tabular}{|c|c|c|c|}
\hline MBPI levels & Amino acids & $\operatorname{MBPI}\left(\mathrm{mg} \mathrm{g}^{-1}\right)$ & FAO/WHO $\left(\mathrm{mg} \mathrm{g}^{-1}\right)$ \\
\hline \multirow[t]{4}{*}{ Overview } & Total amino acids & 800.2 & \\
\hline & Total essential amino acids & $348.2(43.51 \%)^{\mathrm{a}}$ & \\
\hline & Total aromatic amino acids & $96.7(12.08 \%)^{\mathrm{a}}$ & \\
\hline & Total sulfur amino acids & $13.0(1.62 \%)^{\mathrm{a}}$ & \\
\hline \multirow[t]{6}{*}{ Higher levels } & Phenylalanine + Tyrosine & 90.3 & 63 \\
\hline & Leucine & 74 & 66 \\
\hline & Lysine & 62.4 & 58 \\
\hline & Valine & 46.3 & 35 \\
\hline & Isoleucine & 39.1 & 28 \\
\hline & Histidine & 27.9 & 19 \\
\hline \multirow[t]{3}{*}{ Lower levels } & Threonine & 28.4 & 34 \\
\hline & Methionine + cysteine & 13 & 25 \\
\hline & Tryptophan & 6.4 & 11 \\
\hline \multirow{7}{*}{$\begin{array}{l}\text { Not mentioned by the } \\
\text { FAO/WHO }\end{array}$} & Glutamic acid/glutamine & 125.4 & \\
\hline & Aspartic acid/asparagine & 85.3 & \\
\hline & Arginine & 64.4 & \\
\hline & Serine & 38.5 & \\
\hline & Alanine & 36.6 & \\
\hline & Glycine & 32.2 & \\
\hline & Proline & 30 & \\
\hline
\end{tabular}

$\mathrm{MBPI}$, mung bean protein isolates.

apercent of amino acids, relative to total amino acids in MBPI. 
the lack of sulphur-containing amino acids, methionine was successfully introduced into $8 \mathrm{~S} \alpha$ globulin, a major mung bean protein, using protein engineering (20). Consequently, the nutritional quality of the modified protein containing increased methionine in terms of amino acid score improved from 41 to $145 \%$. In a similar vein, Torio et al. (11) reported another protein engineering method that introduced free sulfhydryl groups and disulphide bonds to generate cysteine-modified mung bean $8 \mathrm{~S} \alpha$ globulin to improve nutritional quality.

Meanwhile, the presence of hydrophobic amino acids has been reported to contribute greatly to the thermal and/or conformational stability of globulins to boost yield (10). Consequently, hydrophobic amino acid content increased to $53.1 \%$ in MBPI after substitution of charged amino acids with hydrophobic amino acids.

In addition to the amino acids evaluated using FAO/WHO (15) guidelines mentioned above, other important amino acids omitted from the guidelines should also be mentioned (Table 1). Three of these, glutamic acid, glutamine and arginine, are abundant in mung bean seeds and are thought to be important for brain development, exhibiting neuro-protective functions in infants (21). In addition, dietary glutamine can improve gastrointestinal barrier integrity by reducing systemic infections, and by stimulating lymphocyte proliferation, monocyte function and $\mathrm{T}$ cell 1 helper cytokine responses that may improve brain growth. Glutamine can also reduce systemic inflammation by decreasing the production of pro-inflammatory cytokines (IL-8 and IL-6). Arginine also has some benefits and has been shown to increase cerebral blood flow and increase nitric oxide production to help decrease necrotising enterocolitis incidence.

As mentioned above, non-genetically engineered mung bean proteins contain adequate amounts of most essential amino acids, with the exception of the sulphur-containing amino acids (methionine and cysteine). Methionine and cysteine have previously been obtained dietarily by sulphur-containing amino acids but deficient in lysine (4). A 7:3 ratio of rice protein has been recommended as an optimal ratio for consumption (22).

\section{Mung bean seed proteins}

Mung bean seeds are rich in storage proteins, which account for about $85 \%$ of total protein (9). The crop's major seed storage proteins include albumins, globulins and prolamins, which are soluble in water, in dilute saline and in alcohol-water mixtures, respectively (23). Globulin and albumin, which make up over 60 and 25\% of total mung bean protein, respectively, represent the main mung bean storage proteins. Prolamin, however, has not yet been isolated and characterised from mung bean. Aside from these major proteins, components comprising the other $15 \%$ of mung bean protein components have not yet been extensively studied to date, except for trypsin inhibitor (24), non-specific lipid transfer proteins (nsLTP) (25) and thiamine-binding proteins (26) (Table 2).

Three types of globulins present in mung bean seed have been characterised and are designated as basic-type (7S), vicilin-type (8S) and legumin-type (11S) globulins (5, $27)$, comprising $3.4 \%, 89.0 \%(5,27)$ and $7.6 \%(w / w)$ of total mung bean globulin content, respectively (27).

In mature seeds, the major storage protein is $8 \mathrm{~S}$ globulin, which is the most reported globulin in mung bean proteins (28). No disulphide linkages exist in $8 \mathrm{~S}$ globulin, due to the lack of cysteine content $(19,27,29)$. The $8 \mathrm{~S}$ globulin consists of four subunits with molecular masses ranging from 26 to $60 \mathrm{kDa}$, as observed using SDS-PAGE analysis $(16,27,29)$. Mendoza et al. (27) has determined the N-terminal amino acid sequences of the four mung bean $8 \mathrm{~S}$ globulin subunits, which are EDKEEQ (60 kDa), IDAAEVSVSRGKNNPFYFNN (48 kDa),

Table 2. The composition of major protein fractions and individual protein components in mung bean [Vigna radiata $(\mathrm{L}$.$) ]$

\begin{tabular}{|c|c|c|c|}
\hline Types & Proteins & Subunits & Molecular weight \\
\hline \multirow{8}{*}{$\begin{array}{l}\text { Storage proteins } \\
{[85 \%(9) \text { in overall proteins] }}\end{array}$} & \multirow[t]{7}{*}{ Globulins [60\% (9) in overall proteins] } & \multirow[t]{3}{*}{ Globulin 7S } & $28 \mathrm{kD}(27)$ \\
\hline & & & $16 \mathrm{kD}(27)$ \\
\hline & & & $8 \mathrm{~S}_{\alpha} 5.2 \mathrm{kD}(19)$ \\
\hline & & \multirow[t]{2}{*}{ Globulin 8S } & $8 S_{\alpha}^{\prime} 5.2 k D(19)$ \\
\hline & & & $8 \mathrm{~S}_{\beta} 5.2 \mathrm{kD}(19)$ \\
\hline & & \multirow[t]{2}{*}{ Globulin IIS } & $40 \mathrm{kD}(28)$ \\
\hline & & & $24 \mathrm{kD}(27)$ \\
\hline & Albumin $[25 \%(9)$ in overall proteins] & & \\
\hline \multirow{4}{*}{$\begin{array}{l}\text { Other proteins } \\
\text { ( } 15 \% \text { in overall proteins) }\end{array}$} & Trypsin inhibitor & & I4kD (24) \\
\hline & Non-specific lipid transfer peptide (nsLTP) & & $9.03 \mathrm{kD}(25)$ \\
\hline & Thiamine-binding proteins (TBP) & & $72.6 \mathrm{kD}(26)$ \\
\hline & Others & & \\
\hline
\end{tabular}


SKTLSSQNEPFNLRLN (32 kDa) and IDGAEVSVSRGKNNP (26 kDa).

Three highly conserved isoforms of the $8 \mathrm{~S}$ globulin have been classified as $8 \mathrm{~S} \alpha$ (UniProt ID: B1NPN8_ VIGRA), 8S $\alpha$ ' (UniProt ID: Q198W4_VIGRA) and 8S $\beta$ (UniProt ID: Q198W3_VIGRA) $(9,19)$. Bernardo et al. (19) studied the amino acid sequence homologies of these three isoforms, which were found to be $91-92 \%$ between $8 \mathrm{~S} \alpha$ and $8 \mathrm{~S} \alpha, 87 \%$ between $8 \mathrm{~S} \alpha$ and $8 \mathrm{~S} \beta$, and $86-88 \%$ between $8 \mathrm{~S} \alpha$ ' and $8 \mathrm{~S} \beta$. Another study showed, using the SignalP website server (30), that $8 \mathrm{~S} \alpha, 8 \mathrm{~S} \alpha$ ' and $8 \mathrm{~S} \beta$ signal peptide sequences mapped to residues $1-25,1-24$ or $1-25$, and $1-23$, respectively.

The detailed structure of $8 \mathrm{~S} \alpha$ globulin has been reported to consist of three subunits, each subunit containing two modules. X-ray crystallographic analysis has demonstrated that each module consists of a $\beta$-barrel domain and an extended loop domain (5). The overall $8 \mathrm{~S} \alpha$ globulin structure exhibits $68 \%$ sequence identity and structural similarity (a root-mean-square deviation of 0.6 $\AA$ ) with soybean $\beta$-conglycinin $\beta$ (soybean 7S globulin), and both proteins share surface hydrophobicity characteristics. However, analysis of cavity size and other structural features derived from the mung bean $8 \mathrm{~S} \alpha$ globulin crystal structure suggests that the thermal stability of $8 \mathrm{~S} \alpha$ globulin is lower than that of soybean $\beta$-conglycinin $\beta$.

Methionine and cysteine residues have been introduced into the $8 \mathrm{~S} \alpha$ globulin through protein engineering. Analysis of the methionine-modified mung bean protein, which can possess up to 10 additional methionine residues (20), indicates that the modified $8 \mathrm{~S} \alpha$ globulin exhibits improved structural stability versus the wild-type protein, as assessed by differential scanning calorimetry (DSC). Notably, no allergenic potential has been identified in either wild-type or modified protein. Meanwhile, a report by Torio et al. (11) demonstrated improved structural stability and improved heat-induced gelation properties for cysteine-modified mung bean $8 \mathrm{~S} \alpha$ globulin versus wild-type protein.

To our knowledge, only a limited number of reports covering the characteristics of mung bean $7 \mathrm{~S}$ and $11 \mathrm{~S}$ globulins exist. Mendoza et al. (27) used SDS-PAGE to show that the two bands yielded from 11S globulin were of $40 \mathrm{kDa}$ and $24 \mathrm{kDa}$ in size, whereas the two bands yielded from $7 \mathrm{~S}$ globulin were of $28 \mathrm{kDa}$ and $16 \mathrm{kDa}$ in size. The N-terminal amino acid sequences for these four bands were determined to be NYVMNPAYVLMKPTQKDAAL (for the $28 \mathrm{kDa}$ subunit) and STTVGHSGGTMIST (for the $16 \mathrm{kDa}$ subunit) of $7 \mathrm{~S}$ globulin and SSSSTNNRF [for the $40 \mathrm{kDa}$ acidic subunit (29)] and GLEETIXSSK [for the $24 \mathrm{kDa}$ basic subunit (29)] for the 11S globulin. The presence of disulphide bridges in these $7 \mathrm{~S}$ and $11 \mathrm{~S}$ globulins was demonstrated using SDS-PAGE with and without $\beta$-mercaptoethanol. The 7S and 11S globulins each exhibited only one band in the absence of $\beta$-mercaptoethanol, but two bands in the presence of the reducing agent. Meanwhile, mung bean globulins possessing higher $11 \mathrm{~S}$ to $7 \mathrm{~S}$ globulin ratios were reported to exhibit improved functionalities, for example, solubility and emulsifying activities (29).

Research on mung bean storage proteins has also provided information about this major group of globulins. In one study, Ericson et al. (16) used sucrose gradient centrifugation to show that $8 \mathrm{~S}$ and $11 \mathrm{~S}$ globulins account for approximately 85 and $15 \%$ of total globulins, respectively. In addition, the acidic nature of $11 \mathrm{~S}$ globulins was shown to be less pronounced than that of $8 \mathrm{~S}$ globulins, due to the greater relative prevalence of disulphide bridges between individual acidic and basic polypeptides in $11 \mathrm{~S}$ versus $8 \mathrm{~S}$ globulins (29).

Only a limited number of studies have been carried out regarding mung bean albumin, resulting in deposition of only one albumin sequence in the UniProt database (mung bean seed albumin, UniProt ID: Q43680_VIGRR). However, the reference cited for that entry was not accepted by Plant Molecular Biology. Another mung bean albumin sequence in the UniProt database (albumin 1, UniProt ID: ALB1_VIGRR) does not match with the mung bean sequence reported by Yamazaki et al. (31), the reference cited in the UniProt sequence database.

\section{Functional properties of MBPI}

Functional properties of proteins play a significant role as additives for food processing applications. Therefore, it is necessary to study the physicochemical characteristics of MBPI as food ingredients (32). Recently, several reports have been published regarding functional properties of mung bean proteins (33-35), including protein solubility, water absorption capacity (WAC), oil absorption capacity (OAC), foaming capacity (FC) and foam stability (FS), emulsifying activity (EA) and emulsifying stability (ES), and thermal properties. Consequently, such protein or peptide properties can improve the functionality of food processing applications; for example, the emulsifying property of the protein helps to stabilise emulsions, beverages or foams to prolong food shelf life (33). Functional improvements by MBPI would make it more applicable as food supplements.

\section{Protein solubility}

Solubility is considered as an important functional property of proteins, because it acts as a vital factor of the sensory quality attributes of foods (36). This property is the thermodynamic index of the equilibrium between protein-protein and protein-solvent interactions. Variations in factors, such as temperature, $\mathrm{pH}$, ion strength, freezing, heating and drying, lead to changes in proteins' structural conformations, which in turn affect protein functionality (37). Additionally, $\mathrm{pH}$ value is an important 
index of protein solubility to determine the behaviour of protein isolate in food process.

Due to electrostatic repulsion and hydration, the solubility of MBPI had been higher at $\mathrm{pH}$ values of 2,10 and 12 than that of other $\mathrm{pH}$ values; for example, at $\mathrm{pH} 4$, the lowest solubility was observed and aggregation occurs (38). Du et al. (35) determined that the minimum solubility of MBPI appeared at $\mathrm{pH} 4.6$, which is the isoelectric point. The protein solubility of untreated MBPI was improved by additional heating from 61.5 to $65.6 \%$, which is attributed to increases in charged residues on the MBPI surface, as a result of protein denaturation and/or unfolding (32). Butt and Batool (39) reported that protein solubility of MBPI was $72 \%$ at $\mathrm{pH} 7$. Kudre et al. (10) determined maximum protein solubility of MBPI as $70.6 \%$ at $\mathrm{pH} 10$ (Table 3). They also demonstrated that solubility of MBPI could be improved with the aid of $\mathrm{NaCl}$ at an appropriate concentration. Liu et al. (33) demonstrated that the solubility of mung bean $8 \mathrm{~S}$ globulin ranged from 51.59 to $74.33 \%$, with an average of $64.21 \%$.

\section{WAC and $O A C$}

WAC or OAC is defined as the absorbed amount of water or fat per gram of protein, as protein has both hydrophilic and hydrophobic properties to interact with water and oil in foods. WAC is a useful indication to predict moisture loss if protein isolates can be incorporated into various food products. And OAC can reflect the hydrophobic capacity of protein. A strong negative correlation was found between WAC and OAC (33).

Brishti et al. (38) determined that the WAC and OAC of MBPI were $3.33 \mathrm{~g} \mathrm{~g}^{-1}$ and $3.00 \mathrm{~g} \mathrm{~g}^{-1}$ proteins, respectively. The results imply that MBPI could contribute to the improvement of textural and sensory qualities during processing of fabricated foods because of the proteins capability of retaining water and reducing interfacial tension in an emulsion system. However, Du et al. (35) measured that the highest WAC was $2.62 \mathrm{~mL} \mathrm{~g}^{-1}$, and the OAC was from 9.5 to $10.5 \mathrm{~g} \mathrm{~g}^{-1}$ except at the protein concentration of $1.5 \%$. Butt and Batool (39) reported that WAC and OAC of MBPI were 163 and $113 \%$, respectively (Table 3). In these three reports, similar preparation procedures of MBPI were applied as base extraction and acid precipitation. Liu et al. (33) determined that average WAC and OAC of mung bean $8 \mathrm{~S}$ globulin were $1.92 \mathrm{~g} \mathrm{~g}^{-1}$ and 3.07 $\mathrm{mL} \mathrm{g}^{-1}$, respectively. The varied values of WAC might be due to the protein structure and amount of polar amino acids, whereas the OAC difference might be due to the difference in nonpolar side chains binding the oil.

\section{FC and FS}

Foamability depends on air-liquid interface hydrophobicity, flexibility of protein molecules, protein solubility and denaturability (40). FC describes the stabilising

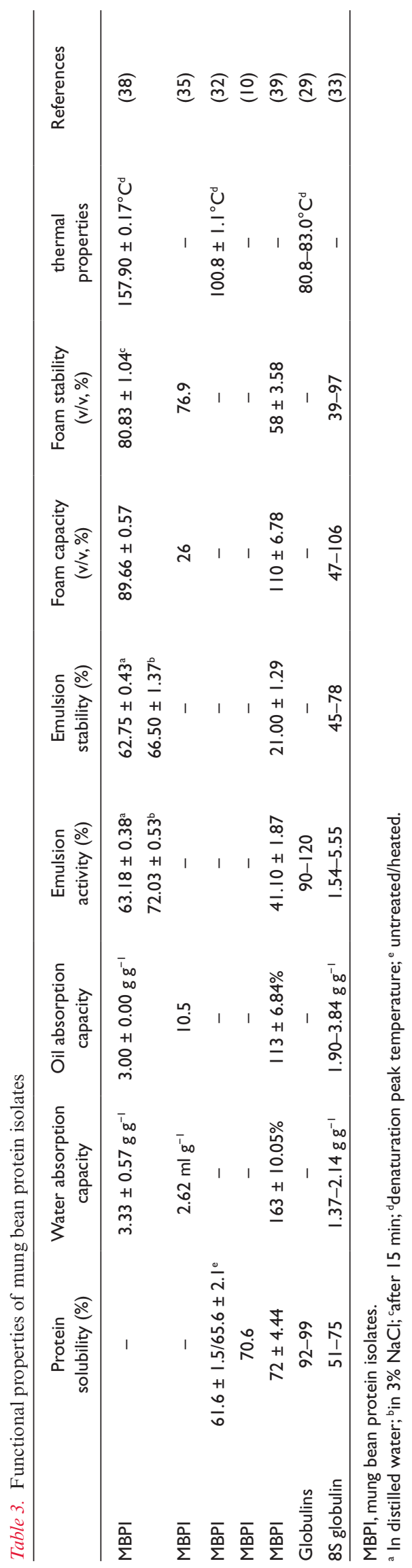


ability of proteins by the amount of interfacial area per unit weight or concentration, and is related to molecular flexibility, charge density and hydrophobicity. And FS is the stabilising ability of proteins to the foam against gravitational and mechanical stresses as the effectiveness of whipping agents relies on their capability to preserve the whip as long as possible, which is affected by rheological properties of protein films, film elasticity and the magnitude of disjoining pressure between the protein layers (40).

Brishti et al. (38) reported that FC and FS of MBPI were 89.66 and $80.83 \%$ after $15 \mathrm{~min}$ of standing time, respectively. Butt and Batool (39) reported that FC and FS of MBPI were 110 and 58\%, respectively. Due to different blending methods and different concentrations of MBPI, Du et al. (35) reported MBPI with 26\% FC and $76.9 \% \mathrm{FS}$ after $10 \mathrm{~min}$ of standing time, respectively (Table 3). This lower FC value might be caused by the high levels of hydrophobic amino acids after homogenisation at 10,000 rpm for $1 \mathrm{~min}$. On the contrary, high FS could be due to the formation of a cohesive continuous network with high elasticity by MBPI, which shows optimum intermolecular interactions and creates stable foams at the air-liquid interface. Liu et al. (33) found significant positive correlation between FC and FS of mung bean $8 \mathrm{~S}$ globulin with average $69.63 \% \mathrm{FC}$ and $61.61 \% \mathrm{FS}$, respectively.

\section{EA and ES}

Emulsifying properties of proteins are also affected by the adsorption ratio of protein at the oil-water interface, the adsorbed amount of protein, interfacial rearrangement of conformation, the reduction degree in interfacial tension and formation of cohesive film (40). In a stabilised solution, EA represents the maximum interfacial area per unit weight of protein, and ES is the measure of the steadiness of emulsion formed by protein.

In $3 \% \mathrm{NaCl}$ and in distilled water, EA and ES of MBPI were found to be 72.03 and 63.18 , and 66.50 and $62.75 \%$, respectively (38) (Table 3). Butt and Batool (39) reported that EA and ES of MBPI was 41.10 and $21 \%$, respectively (Table 3). Liu et al. (33) determined that average EA index and ES of mung bean $8 \mathrm{~S}$ globulin from different mung bean cultivars were $3.46 \mathrm{~m}^{2} \mathrm{~g}^{-1}$ and $63.15 \%$, respectively. In chopped and fabricated meat-based products, EA and ES are critical factors. Since EA and ES of MBPI had been rather high comparing to other legumes (38), MBPI can be applied in both formation and stabilisation of fluid emulsion during the production of heat-treated textured vegetable proteins.

\section{Thermal properties}

The thermal properties of proteins, for example, denaturation of proteins, are often determined as an endothermic peak on the thermogram by DSC (41). Brishti et al. (38) reported that the denaturation temperature of MBPI was at $157.90^{\circ} \mathrm{C}$, which is a transition temperature accompanied by rupture of intramolecular bonds when MBPI are heated from native to denatured state. Tang et al. (29) determined that the denaturation temperature of mung bean globulins was from 80.8 to $83.0^{\circ} \mathrm{C}$ (Table 3). Tang et al. (40) found that disulphide bonds within the protein molecule contribute to the thermal stability of protein. Kudre et al. (10) stated that the high thermal stability attribute could be due to the disulphide bonds, whereas the presence of salt bridges in the hydrophobic clefts of protein structure makes it more thermostable. In the process of optimisation of temperature, such as extrusion and heat treatment, the analysis of thermal properties of MBPI serves as an important tool.

\section{Extraction of mung bean proteins and peptides}

Extraction of mung bean proteins has been widely studied. As a key step in mung bean protein research, many methods of protein extraction have been established. These methods are classified into two types, salt extraction methods and methods consisting of base extraction and acid precipitation. In order to isolate specific mung bean proteins, additional steps have been added to separation procedures, for example, heat treatment and Sephadex G-50 separation were used as additional steps for trypsin inhibitor isolation (24).

\section{Salt extraction method}

Johns et al. (42) reported an extraction method using a saturated ammonium sulphate solution. Mung bean proteins have also been extracted in $5 \% \mathrm{NaCl}$ solutions, which was the optimum $\mathrm{NaCl}$ concentration to achieve a maximum total protein dissolution of $87.5 \%$. Globulins have also been precipitated using saturated ammonium sulphate solution with concentrations of 20 and $65 \%$ for precipitating $\alpha$-globulin and $\beta$-globulin, respectively, after which albumin was recovered from the dialysed supernatant liquid and isolated by coagulation. The yields of $\alpha$-globulin and $\beta$-globulin were 0.35 and $5.75 \%$ (w/w), respectively, based on the dry weight of mung bean flour extracted, whereas the albumin yield ranged from 0.02 to $0.05 \%(w / w)$ of dry flour weight.

Using a different strategy, Rahma et al. (43) used a salt extraction method involving micellisation of mung bean proteins from a $0.5 \mathrm{~mol} \mathrm{~L}^{-1}$ sodium chloride water solution. The procedure consisted of extraction, centrifugation, filtration and micellisation steps. The micellised protein was separated by centrifugation, washed with water and redissolved at $\mathrm{pH} 7$ by addition of sodium hydroxide. Basic $7 \mathrm{~S}$ globulin was subsequently found to be easily extracted with $0.15 \mathrm{~mol} \mathrm{~L}^{-1} \mathrm{NaCl}$, whereas $11 \mathrm{~S}$ globulin was extracted using $0.35 \mathrm{~mol} \mathrm{~L}^{-1} \mathrm{NaCl}$. 


\section{The method of base extraction and acid precipitation}

Rahma et al. (43) also established a method of base extraction and acid precipitation, and compared it to the salt extraction method outlined above. Briefly, the procedure included alkaline water extraction at $\mathrm{pH} 8$ (using a flour to water ratio of 1:20 w/v) followed by isoelectric precipitation at $\mathrm{pH} 4.5$, washing, re-dissolution at $\mathrm{pH} 7$ using $0.1 \mathrm{~mol} \mathrm{~L}^{-1}$ sodium hydroxide and centrifugation. Ultimately, 7S globulin, a predominant storage protein, was isolated using this method and $11 \mathrm{~S}$ globulin was also isolated and determined to be a disulphide-linked polypeptide chain.

Comparative analysis suggested that the salt extraction method was much better for enrichment of the $7 \mathrm{~S}$ globulin. Meanwhile, Thompson et al. (12) reported another method of base extraction and acid precipitation for the preparation of MBPIs. Numerous parameters, including $\mathrm{pH}$, temperature, extraction time and ratio of mung bean flour to solvent, were optimised to increase the yield of protein extracted from mung bean flour. The highest yield of mung bean protein was achieved with the following optimised parameters: extraction at $\mathrm{pH} 9$ at $25^{\circ} \mathrm{C}$ for 20 min with a 1:15 ratio of mung bean flour to solvent, followed by precipitation at $\mathrm{pH}$ 4. Subsequently, Kudre et al. (10) and El-Adawy (44) reported similar methods for MBPI whereby mung bean seed flour was extracted with $\mathrm{NaOH}$ ( $\mathrm{pH}$ 12) or $0.1 \mathrm{~mol} \mathrm{~L}^{-1} \mathrm{NaOH}$ ( $\mathrm{pH}$ 9), respectively. Next, both extractions were precipitated with $\mathrm{HCl}(\mathrm{pH}$ $4.5)$, followed by centrifugation and washing. Kudre et al. obtained approximately $87.8 \%$ of MBPI from dry mung bean seeds, whereas El-Adawy reported an average yield of $13 \mathrm{~g}$ protein $/ 100 \mathrm{~g}$ mung bean flour.

In addition, other methods incorporating additional steps have been used to isolate specific bioactive proteins, such as trypsin inhibitor protein (24) and nsLTP (25). Klomklao et al. (24) found that the highest trypsin inhibitor activity of 822.63 unit $\mathrm{g}^{-1}$ seed and specific trypsin in-

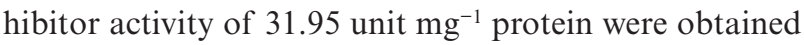
using distilled water extraction. Moreover, certain salt and alkaline conditions were observed to increase protein solubility, leading to a reduction in specific trypsin inhibitor activity [as observed in other studies of other legumes (45-47)]. Subsequently, a final specific inhibitory activity of 406 unit $\mathrm{mg}^{-1}$ protein was achieved after heat treatment, ammonium sulphate precipitation (30-65\%) and Sephadex G-50 isolation. Ultimately, trypsin inhibitor activity was higher by about 13-fold compared to crude extract, with a yield of purified trypsin inhibitor from the extract of $30.25 \%$. Meanwhile, Wang et al. (25) extracted anti-fungal nsLTP from ammonium sulphate precipitates coupled with purification using both CM-Sephadex C-50 and POROS-HS chromatography to isolate purified nsLTP, yielding $13 \mathrm{mg}$ nsLTP from $100 \mathrm{~g}$ mung bean seeds.

\section{Bioactivities of mung bean proteins and peptides}

Many different kinds of bioactive proteins and peptides have been reported from mung bean seeds. These proteins and peptides exhibit bioactivities, which may be beneficial to human beings and animals, including ACE inhibitors, trypsin inhibitor and anti-fungal agents.

\section{ACE inhibitory activity}

Several diverse biological pathways are known to regulate blood pressure in living organisms. One pathway, the renin angiotensin system, has been demonstrated to be acted upon by hypotensive peptides (31). Within the renin-angiotensin system, conversion of angiotensinogen to the pre-hypertensive hormone angiotensin I (DRVYIHPFHL) occurs through the action of renin secreted by the kidneys. Angiotensin I is further converted by ACE to angiotensin II (DRVYIHPF), which is the active form of the hormone, by ACE. Angiotensin II raises blood pressure by acting directly on blood vessels, sympathetic nerves and adrenal glands (48). Inhibition of ACE by ACE inhibitors is a strategy used to control hypertension.

ACE inhibitory activity is one of the main bioactivities reported for plant food-derived peptides (49). Aluko (50) reported that hydrolysed proteins from three legume sources, including mung bean, could provide ACE inhibitory activity. Indeed, food-derived ACE inhibitory peptides may be an alternative to synthetic drugs, since peptides are thought to cause fewer side effects (51). Consequently, Li et al. (52) have demonstrated that MBPI hydrolysed by Alcalase ${ }^{\mathrm{TM}}$ showed ACE inhibitory activity at a half maximal inhibitory concentration (IC50) of $0.64 \mathrm{mg}$ protein $\mathrm{mL}^{-1}$. Using this method, the highest ACE inhibitory activity (53) was observed for a hydrolysate generated by Alcalase ${ }^{\mathrm{TM}}$ after $2 \mathrm{~h}$ of hydrolysis.

Meanwhile, another study demonstrated that a significant decrease in systolic blood pressure was observed in spontaneously hypertensive rats after ingestion of hydrolysed mung bean peptides. More recently, Li et al. (54) isolated three antihypertensive peptides from an Alcalase $^{\mathrm{TM}}$-hydrolysated mung bean preparation using Sephadex G-15 and reverse-phase high-performance liquid chromatography (RP-HPLC) purification steps. The three peptides were identified by amino acid composition analysis and matrix-assisted-laser desorption/ionisation timeof-flight tandem mass spectrometry (MALDI-TOF MS/ MS), as KDYRL, VTPALR and KLPAGTLF, with IC50 values of $26.5,82.4$ and $13.4 \mu \mathrm{M}$, respectively. Concurrently, using a different strategy, Lactobacillus plantarum B1-6-fermented mung bean milk was shown to produce significantly higher ACE inhibitory activity (67.5\%) at the end of fermentation. Production of inhibitory peptides coincided with the disappearance of larger/more hydrophobic peptides with the appearance of increasing 
amounts of smaller/more hydrophilic peptides using RP-HPLC (55).

Using a different strategy, Mamilla et al. (56) compared mung bean grain and germinated seeds for ACE inhibitors using an in vitro ACE inhibition assay. Protein hydrolysates of germinated mung bean seeds showed greater than $82 \%$ ACE inhibition, reaching an IC50 value of $0.025 \mathrm{mg}$ $\mathrm{mL}^{-1}$. However, the activities of ACE inhibitory peptides in vitro based on chemical tests are not always mirrored by their hypotensive effect in vivo on animal studies (57). Therefore, most of the presented studies should be treated with great caution due to the general poor correlation between in vitro biochemical assays on ACE and physiological responses in vivo. After all, many of the peptides, which show good activity in vitro, are degraded in the GI system, hence, explaining the unreliability of the assay results.

\section{Trypsin inhibitory activity}

Proteinase inhibitors, especially food-additive grade inhibitors, are in demand for protecting myofibrillar proteins from proteolysis by endogenous proteinases. Such inhibitors from legume sources, which generally inhibit trypsin, are safe, effective, thermally stable and inexpensive (10). For example, due to their inhibitory ability toward proteinases, trypsin inhibitors from legume seeds have been used for prevention of softening of mince or surimi gel mediated by heat-activated proteinases that are abundant in fish muscle or surimi (58). Subsequently, Sun et al. (59) reported that mung bean trypsin inhibitor additives were effective in preventing softening of surimi gel from marine fish blue scad. The fact that trypsin inhibitors from mung bean seeds are safe and effective in inhibiting trypsin activity suggests that their use as ingredients in drug formulations may prevent trypsin hydrolysis during drug administration.

Studies of purified mung bean trypsin inhibitor are beginning to shed light on this protein's specific functions. In one study, Chrispeels et al. (60) reported trypsin inhibitory activity from the mung bean seed extracts prepared by a method of base extraction and acid precipitation followed by trypsin-sepharose affinity chromatography. They found that the purified trypsin inhibitor was not a double-headed inhibitor containing inhibitory sites for both trypsin and chymotrypsin, as observed in soybean trypsin inhibitor (61). Moreover, an aliquot $(2.5 \mu \mathrm{l})$ of the purified trypsin inhibitor solution corresponding to one unit of trypsin activity did not inhibit vicilin peptidohydrolase, the major endopeptidase in the cotyledons of mung bean seedlings. In another study, Lorensen et al. (62) reported that six species of trypsin inhibitors, one major (F) and five minor inhibitor species (A-E), were observed in mung bean seeds, with overall trypsin inhibitory activity reported to be equivalent to $1.8 \mathrm{U} \mathrm{g} \mathrm{g}^{-1}$ of dry seed weight. More recently, Wilson et al. (63) determined the sequences of trypsin inhibitors $\mathrm{C}, \mathrm{E}, \mathrm{F}$ using a combination of automatic solid-phase and manual sequencing techniques. Analysis of trypsin inhibitor F showed that it contains 80 amino acid residues and exhibits a high degree of identity with the other sequenced members of the Bowman-Birk family of protease inhibitors. Trypsin inhibitors $\mathrm{E}, \mathrm{E}^{\prime}$ and $\mathrm{C}$ are derived from inhibitor $\mathrm{F}$ by limited specific proteolysis. Notably, the majority cleavage sites noted in the $\mathrm{F}-\mathrm{E}-\mathrm{C}-\mathrm{E}$ ' inhibitors were found to occur at peptide bonds involving aspartyl residues. Currently, two sequences of trypsin inhibitors are reported in the UniProt Database (http://www.uniprot.org/), that is, BowmanBirk trypsin inhibitor (UniProt ID: IBB_VIGRR) and trypsin inhibitor (UniProt ID: Q1WA44_VIGRA). High conservation of these sequences related to other trypsin inhibitors has been reported (Table 4).

\section{Anti-fungal and/or antibacterial activities}

The anti-fungal and antibacterial protein, nsLTP (a basic, $9.03 \mathrm{kDa}$ protein), which displays anti-pathogenic activity, has been isolated from the mung bean (Vigna radiata) seeds (25). The nsLTP protein is able to bind and transfer a variety of very diverse lipids between membranes in vitro (48). The $\mathrm{N}$-terminal sequence of nsLTP was determined to be MTCGQVQGNL AQCIGFLEKG G. It exerts anti-fungal action toward Fusarium solani, Fusarium oxysporum, Pythium aphanidermatum and Sclerotium rolfsii and antibacterial action against Staphylococcus aureus, but not Salmonella typhimurium. The lipid-binding ability of the protein is very similar to that of previously described lipid transfer proteins extracted from wheat and maize seeds, indicating that it possesses lipid transfer activity (64).

Ye et al. (65) isolated an anti-fungal protein, mungin, from mung bean (Vigna radiata) seeds. Interestingly, mungin, an $18 \mathrm{kDa}$ protein, possesses a novel N-terminal sequence homologous to cyclophilins. The N-terminal sequence of mungin is PNPKVFFDMT IGGQPAGKIV FELFADTTPR TAENFRALTT GEKGVSRGRK PLHYHGSIFH R. Mungin was shown to have anti-fungal activity against Rhizoctonia solani, Coprinus comatus and

Table 4. The sequences of the mung bean trypsin inhibitors reported in UniProt database

\begin{tabular}{ll}
\hline UniProt ID & UniProt sequence \\
\hline IBB_VIGRR & SHDEPSESSE PCCDSCDCTK SIPPECHCAN \\
& IRLNSCHSAC KSCICTRSMP GKCRCLDTDD \\
& FCYKPCESMD KD \\
QIWA44_VIGRA & MMVLKVCVLVVFVGVTTAG MDLNQLRSSH \\
& HHDSSDEPSE SSEPCCDSCR CTKSIPPQCH \\
& CADIRLNSCH SACKSCMCTR SMPGKCRCLD \\
& TDDFCYKPCE SMDKDDD \\
\hline
\end{tabular}


Botrytis cinerea and to a lesser extent on Mycosphaerella arachidicola and Fusarium oxysporum. Mungin also displayed inhibitory activity against $\alpha$ - and $\beta$-glucosidases but not against HIV-1 reverse transcriptase and $\beta$-glucuronidase. It is noteworthy that mungin, as a cyclophilinlike anti-fungal protein, also exhibited anti-mitogenic activity (66).

\section{Conclusion}

MBPI have been reported to possess a nutritional-balanced amino acid composition using recommended FAO/WHO guidelines, with the exception of a deficiency in except sulphur-containing amino acids. However, protein engineering technology has been applied to introduce additional methionine and cysteine residues into mung bean $8 \mathrm{~S}$ globulin to boost the methionine percentage from 41 to $145 \%$. In a similar way, a free sulfhydryl group (cysteine residue) was introduced and the presence of a new disulphide bond was confirmed in cysteine-modified globulin.

The functional properties of MBPI, that is, protein solubility, WAC, OAC, FC and FS, EA and ES, and thermal properties, are useful properties for food-processing applications. Studies on MBPI functionality have been carried out for the development of food industry applications.

Extraction methods have allowed purification of several mung bean proteins and peptides from mung bean flour, paving the way for functional analyses. Extraction methods that alter the ionic environment, combined with alkaline extraction and acid precipitation, have been used most often. Notably, varies extraction ratios of various mung bean proteins can be obtained using various strategies. Globulins, the major proteins present in mung beans, account for about $85 \%$ of total protein. The subunit structure, N-terminal amino acid sequence, structure and homology amongst the three distinct isoforms of $8 \mathrm{~S} \alpha$ globulin have been described in detail. However, the reports on mung bean albumins need to be clarified.

In addition, bioactive proteins and peptides hold special interest due to their potential health benefits in addition to their known nutritional functions. Specifically, ACE inhibitor and anti-fungal activities of mung bean protein hydrolysates and peptides have medical use, whereas trypsin inhibitors in mung bean protein fractions may serve as additive for preventing food proteolysis. Therefore, mung bean proteins and their hydrolysates hold great promise as sources of compounds with significant nutritional, functional and bioactive potential uses in foods, pharmaceuticals, other products and processes.

\section{Acknowledgements}

This study was part of a project funded by the Priority Academic Program Development of Jiangsu Higher Education Institutions, China, and was supported by China Scholarship Council.

\section{Conflict of interest and funding}

The authors have not received any funding or benefits from industry or elsewhere to conduct this study.

\section{References}

1. Espin JC, Garcia-Conesa MT, Tomas-BarberanFA. Nutraceuticals: facts and fiction. Phytochemistry 2007; 68(22-24): 2986-3008. doi: 10.1016/j.phytochem.2007.09.014. PubMed PMID: 17976666.

2. Del Rosario RR, Flores DM. Functional properties of four types of mung bean flour. J Sci Food Agr 1981; 32(2): 175-80. doi: 10.1002/jsfa.2740320213.

3. Tang D, Dong Y, Ren H, Li L, He C, et al. A review of phytochemistry, metabolite changes, and medicinal uses of the common food mung bean and its sprouts (Vigna radiata). Chem Central J 2014; 8: 4. doi: 10.1186/1752-153x-8-4. PubMed PMID: WOS:000334627400001.

4. Dahiya PK, Linnemann AR, Van Boekel MA, Khetarpaul N, Grewal RB, Nout MJ. Mung bean: technological and nutritional potential. Crit Rev Food Sci Nutr 2015; 55(5): 670-88. doi: 10.1080/10408398.2012.671202. PubMed PMID: 24915360 .

5. Itoh T, Garcia RN, Adachi M, Maruyama Y, Tecson-Mendoza EM, Mikami B, et al. Structure of $8 \mathrm{~S} \alpha$ globulin, the major seed storage protein of mung bean. Acta Crystallogr D Biol Crystallogr 2006; 62(7): 824-32. doi: 10.1107/s090744490601804x.

6. Anwar F, Latif S, Przybylski R, Sultana B, Ashraf M. Chemical composition and antioxidant activity of seeds of different cultivars of mung bean. J Food Sci 2007; 72(7): S50310. doi: 10.1111/j.1750-3841.2007.00462.x. PubMed PMID: 17995664.

7. Xu XP, Liu H, Tian LH, Dong XB, Shen SH, Qu LQ. Integrated and comparative proteomics of high-oil and high-protein soybean seeds. Food Chem 2015; 172: 105-16. doi: 10.1016/j.foodchem.2014.09.035. PubMed PMID: WOS:000345207200015.

8. Shevkani K, Singh N, Kaur A, Rana JC. Structural and functional characterization of kidney bean and field pea protein isolates: a comparative study. Food Hydrocolloids 2015; 43: 679-89. doi: 10.1016/j.foodhyd.2014.07.024. PubMed PMID: WOS:000345683500078.

9. Chen M-X, Zheng S-X, Yang Y-N, Xu C, Liu J-S, Yang W-D, et al. Strong seed-specific protein expression from the Vigna radiata storage protein $8 \mathrm{SG}$ alpha promoter in transgenic Arabidopsis seeds. J Biotechnol 2014; 174: 49-56. doi: 10.1016/j. jbiotec.2014.01.027. PubMed PMID: WOS:000333089700010.

10. Kudre TG, Benjakul S, Kishimura H. Comparative study on chemical compositions and properties of protein isolates from mung bean, black bean and bambara groundnut. J Sci Food Agr 2013; 93(10): 2429-36. doi: 10.1002/jsfa.6052.

11. Torio MAO, Itoh T, Garcia RN, Maruyama N, Utsumi S, Tecson-Mendoza EM. Introduction of sulfhydryl groups and disulfide linkage to mungbean $8 \mathrm{~S} \alpha$ globulin and effects on physicochemical and functional properties. Food Res Int 2012; 45(1): 277-82. doi: 10.1016/j.foodres.2011.10.044.

12. Thompson LU. Preparation and evaluation of mung bean protein isolates. J Food Sci 1977; 42(1): 202-6. PubMed PMID: ISI:A1977CP78700049; English.

13. Mubarak AE. Nutritional composition and antinutritional factors of mung bean seeds (Phaseolus aureus) as affected by some home traditional processes. Food Chem 2005; 89(4): 489-95. doi: 10.1016/j.foodchem.2004.01.007. PubMed PMID: WOS:000224329600001. 
14. FAO/WHO. Energy and protein requirements. Report of FAO Nutritional Meeting Series No 52, 1973. Rome: FAO.

15. FAO/WHO. Protein quality evaluation. Joint FAO/WHO. FAO Food Nutr Paper 1991; 51: 1-66. PubMed PMID: MEDLINE: 1817076.

16. Ericson MC, Chrispeels MJ. Isolation and characterization of glucosamine-containing storage glycoproteins from the cotyledons of phaseolus aureus. Plant Physiol 1973; 52(2): 98-104. doi: 10.1104/pp.52.2.98. PubMed PMID: MEDLINE:16658529.

17. Bhattacharyya SP, Biswas BB. Purification and characterization of high salt-soluble vicilin from mung bean(Vignaradiata). Biochem Int 1990; 21(4): 667-75. PubMed PMID: WOS:A1990DX01900010.

18. Khalil AA. Nutritional improvement of an Egyptian breed of mung bean by probiotic lactobacilli. Afr J Biotechnol 2006; 5(2): 206-12. PubMed PMID: WOS:000235140100026.

19. Bernardo AEN, Garcia RN, Adachi M, Angeles JGC, Kaga A, Ishimoto $\mathrm{M}$, et al. $8 \mathrm{~S}$ globulin of mungbean Vigna radiata (L.) wilczek: cloning and characterization of its cDNA isoforms, expression in Escherichia coli, purification, and crystallization of the major recombinant $8 \mathrm{~S}$ isoform. J Agr Food Chem 2004; 52(9): 2552-60. doi: 10.1021/jf0305938. PubMed PMID: WOS:000221135100021.

20. Torio MAO, Adachi M, Garcia RN, Prak K, Maruyama N, Utsumi S, et al. Effects of engineered methionine in the $8 \mathrm{~S}$ alpha globulin of mungbean on its physicochemical and functional properties and potential nutritional quality. Food Res Int 2011; 44(9): 2984-90. doi: 10.1016/j.foodres.2011.07.010. PubMed PMID: WOS:000296798300054.

21. Keunen K, van Elburg RM, van Bel F, Benders M. Impact of nutrition on brain development and its neuroprotective implications following preterm birth. Pediatr Res 2015; 77(1): 148-55. doi: 10.1038/pr.2014.171. PubMed PMID: WOS:000347672800007.

22. Florentino RF. Nutritional aspects of eating rice. Philippine $J$ Nutr 1974; 27(4): 129-40. PubMed PMID: 1976:3502; English.

23. Shewry PR, Napier JA, Tatham AS. Seed storage proteins Structures and biosynthesis. Plant Cell 1995; 7(7): 945-56. doi: 10.1105/tpc.7.7.945. PubMed PMID: WOS:A1995RM93700014.

24. Klomklao S, Benjakul S, Kishimura H, Chaijan M. Extraction, purification and properties of trypsin inhibitor from Thai mung bean (Vigna radiata (L.) R. Wilczek). Food Chem 2011; 129(4): 1348-54. doi: 10.1016/j.foodchem.2011.05.029. PubMed PMID: WOS:000294979600004.

25. Wang SY, Wu JH, Ng TB, Ye XY, Rao PF. A non-specific lipid transfer protein with antifungal and antibacterial activities from the mung bean. Peptides 2004; 25(8): 1235-42. doi: 10.1016/j. peptides.2004.06.004. PubMed PMID: ISI:000223926700002; English.

26. Gunarti DR, Rahmi H, Sadikin M. Isolation and purification of thiamine binding protein from mung bean. HAYATI J Biosci 2013; 20(1): 1-6. doi: 10.4308/hjb.20.1.1.

27. Mendoza EMT, Adachi M, Bernardo AEN, Utsumi S. Mungbean [Vigna radiata (L.) Wilczek] globulins: purification and characterization. J Agr Food Chem. 2001; 49(3): 1552-8. doi: 10.1021/Jf001041h. PubMed PMID: ISI:000168967400081; English.

28. Wang J, Tse YC, Hinz G, Robinson DG, Jiang L. Storage globulins pass through the Golgi apparatus and multivesicular bodies in the absence of dense vesicle formation during early stages of cotyledon development in mung bean. J Exp Bot 2012; 63(3): 1367-80. doi: 10.1093/jxb/err366. PubMed PMID: WOS:000300238400025.
29. Tang C-H, Sun X. Physicochemical and structural properties of $8 \mathrm{~S}$ and/or 11S globulins from mungbean [Vigna radiata(L.) Wilczek] with various polypeptide constituents. J Agr Food Chem. 2010; 58(10): 6395-402. doi: 10.1021/jf904254f.

30. Nielsen H, Engelbrecht J, Brunak S, von Heijne G. Identification of prokaryotic and eukaryotic signal peptides and prediction of their cleavage sites. Protein Eng 1997; 10(1): 1-6. doi: 10.1093/protein/10.1.1. PubMed PMID: WOS:A1997WJ04100001.

31. Yamazaki T, Takaoka M, Katoh E, Hanada K, Sakita M, Sakata K, et al. A possible physiological function and the tertiary structure of a $4-\mathrm{kDa}$ peptide in legumes. Eur J Biochem 2003; 270(6): 1269-1276. doi: 10.1046/j.1432-1033.2003.03489.x. PubMed PMID: ISI:000181549200024; English.

32. Tang $\mathrm{CH}$, Sun $\mathrm{X}$, Yin SW. Physicochemical, functional and structural properties of vicilin-rich protein isolates from three Phaseolus legumes: effect of heat treatment [Article]. Food Hydrocolloid 2009; 23(7): 1771-8. doi: 10.1016/j. foodhyd.2009.03.008. PubMed PMID: WOS:000267478400018; English.

33. Liu H, Liu H, Yan L, Cheng X, Kang Y. Functional properties of $8 \mathrm{~S}$ globulin fractions from 15 mung bean (Vigna radiata (L.) Wilczek) cultivars. Int J Food Sci Technol 2015; 50(5): 1206-14. doi: 10.1111/ijfs. 12761 .

34. Tang C-H. Thermal denaturation and gelation of vicilin-rich protein isolates from three Phaseolus legumes: a comparative study. LWT-Food Sci Technol 2008; 41(8): 1380-8. doi: 10.1016/j. lwt.2007.08.025. PubMed PMID: WOS:000256831700004.

35. Du M, Xie J, Gong B, Xu X, Tang W, Li X, et al. Extraction, physicochemical characteristics and functional properties of Mung bean protein. Food Hydrocolloid 2018; 76(Suppl C): 131-140. doi: https://doi.org/10.1016/j.foodhyd.2017.01.003.

36. Suppavorasatit I, Lee S-Y, Cadwallader KR. Effect of enzymatic protein deamidation on protein solubility and flavor binding properties of soymilk. J Food Sci 2013; 78(1): C1-C7. doi: 10.1111/j.1750-3841.2012.03012.x.

37. Damodaran S, Parkin KL, Fennema OR. Fennema's food chemistry. Boca Raton, FL: CRC Press/Taylor \& Francis; 2008.

38. Brishti FH, Zarei M, Muhammad SKS, Ismail-Fitry MR, Shukri $\mathrm{R}$, Saari N. Evaluation of the functional properties of mung bean protein isolate for development of textured vegetable protein. Int Food Res J 2017; 24(4): 1595.

39. Butt MS, Batool R. Nutritional and functional properties of some promising legumes protein isolates. Pak J Nutr 2010; 9(4): 373-9. doi: 10.3923/pjn.2010.373.379.

40. Wright DJ, Hemmant JW. Foaming properties of protein solutions: comparison of large-scale whipping and conductimetric methods. J Sci Food Agr 1987; 41(4): 361-71. doi: 10.1002/ jsfa.2740410408.

41. Tang CH, Chen L, Ma CY. Thermal aggregation, amino acid composition and in vitro digestibility of vicilin-rich protein isolates from three Phaseolus legumes: a comparative study [Article]. Food Chem 2009; 113(4): 957-63. doi: 10.1016/j.foodchem.2008.08.038. PubMed PMID: WOS:000261857100015; English.

42. Johns CO, Waterman HC. Some proteins from the mung bean, Phaseolus aureus Roxburgh. J Biol Chem 1920; 44: 303-17. PubMed PMID: 1921:6398; language unavailable.

43. Rahma EH, Dudek S, Mothes R, Gornitz E, Schwenke KD. Physicochemical characterisation of mung bean (Phaseolus aureus) protein isolates. J Sci Food Agr 2000; 80(4): 477-83. PubMed PMID: ISI:000085726100008; English.

44. El-Adawy TA. Functional properties and nutritional quality of acetylated and succinylated mung bean protein isolate. Food 
Chem 2000; 70(1): 83-91. PubMed PMID: ISI:000086844300014; English.

45. Deshpande SS, Campbell CG. Effect of different solvents on protein recovery and neurotoxin and trypsin-inhibitor contents of grass pea(Lathyrus-sativus). J Sci Food Agr 1992; 60(2): 245-9. doi: 10.1002/jsfa.2740600213. PubMed PMID: WOS:A1992KA88300012.

46. Benjakul S, Visessanguan W, Thummaratwasik P. Isolation and characterization of trypsin inhibitors from some Thai legume seeds. J Food Biochem 2000; 24(2): 107-27. doi: 10.1111/j.1745-4514.2000.tb00689.x. PubMed PMID: WOS:000087229900002.

47. Klomklao S, Benjakul S, Kishimura H, Osako K, Tanaka M. A heat-stable trypsin inhibitor in adzuki bean (Vigna angularis): effect of extraction media, purification and biochemical characteristics. Int J Food Sci Technol 2010; 45(1): 163-9. doi: 10.1111/j. 1365-2621.2009.02117.x.PubMedPMID:WOS:000272655500021.

48. Kader JC. Lipid-transfer proteins in plants. Annu Rev Plant Phys 1996; 47: 627-54. doi: 10.1146/annurev.arplant.47.1.627. PubMed PMID: ISI:A1996UT11900024; English.

49. Guang C, Phillips RD. Plant food-derived angiotensin I converting enzyme inhibitory peptides [review]. J Agr Food Chem 2009; 57(12): 5113-20. doi: 10.1021/jf900494d. PubMed PMID: WOS:000267183800001; English.

50. Aluko RE. Determination of nutritional and bioactive properties of peptides in enzymatic pea, chickpea, and mung bean protein hydrolysates. J Aoac Int 2008; 91(4): 947-56. PubMed PMID: ISI:000258270400033; English.

51. García MC, Puchalska P, Esteve C, Marina ML. Vegetable foods: a cheap source of proteins and peptides with antihypertensive, antioxidant, and other less occurrence bioactivities. Talanta 2013; 106: 328-49. doi: 10.1016/j.talanta.2012.12.041.

52. Li GH, Shi YH, Liu H, Le GW. Antihypertensive effect of alcalase generated mung bean protein hydrolysates in spontaneously hypertensive rats. Eur Food Res Technol 2006; 222(5-6): 733-6. doi: 10.1007/s00217-005-0147-2. PubMed PMID: ISI:000235900700035; English.

53. Liu F, Zhang XB, Lu CM, Zeng XH, Li YJ, Fu DH, et al. Non-specific lipid transfer proteins in plants: presenting new advances and an integrated functional analysis. J Exp Bot 2015; 66(19): 5663-81. doi: 10.1093/jxb/erv313. PubMed PMID: ISI:000362073400003; English.

54. Li GH, Wan JZ, Le GW, Shi YH. Novel angiotensin I-converting enzyme inhibitory peptides isolated from Alcalase hydrolysate of mung bean protein. J Peptide Sci 2006; 12(8): 509-14. doi: 10.1002/ Psc.758. PubMed PMID: ISI:000239879000003; English.

55. Wu H, Rui X, Li W, Chen X, Jiang M, Dong M. Mung bean (Vigna radiata) as probiotic food through fermentation with Lactobacillus plantarum B1-6. LWT - Food Sci Technol 2015; 63(1): 445-51. doi: 10.1016/j.lwt.2015.03.011.

56. Mamilla RK, Mishra VK. Effect of germination on antioxidant and ACE inhibitory activities of legumes. LWT
- Food Sci Technol 2017; 75(Suppl C): 51-8. doi: 10.1016/j. lwt.2016.08.036.

57. He H-L, Liu D, Ma C-B. Review on the angiotensin-I-converting enzyme (ACE) inhibitor peptides from marine proteins. Appl Biochem Biotech 2013; 169(3): 738-49. doi: 10.1007/ s12010-012-0024-y.

58. Benjakul S, Karoon S, Suwanno A. Inhibitory effects of legume seed extracts on fish proteinases. J Sci Food Agr 1999; 79(13): 1875-81. doi: 10.1002/(sici)1097-0010(199910)79:13<1875::aid-jsfa447>3.0.co;2-u. PubMed PMID: WOS:000082956500016.

59. Sun L-C, Yoshida A, Cai Q-F, Liu G-M, Weng L, Tachibana $\mathrm{K}$, et al. Mung bean trypsin inhibitor is effective in suppressing the degradation of myofibrillar proteins in the skeletal muscle of blue scad (Decapterus maruadsi). J Agr Food Chem 2010; 58(24): 12986-92. doi: 10.1021/jf103526e. PubMed PMID: WOS:000285236400057.

60. Chrispeels MJ, Baumgartner B. Trypsin-inhibitor in mung bean cotyledons-purification, characteristics, subcellular-localization, and metabolism. Plant Physiol 1978; 61(4): 617-23. doi: 10.1104/ pp.61.4.617. PubMed PMID: WOS:A1978EY11600030.

61. Kunitz M. Crystalline soybean trypsin inhibitor: II. General properties. J Gen Physiol 1947; 30(4): 291-310. doi: 10.1085/ jgp.30.4.291. PubMed PMID: MEDLINE:19873496; English.

62. Lorensen E, Prevosto R, Wilson KA. The appearance of new active forms of trypsin-inhibitor in germinating mung bean(Vigna-radiata) seeds. Plant Physiol 1981; 68(1): 88-92. doi: 10.1104/pp.68.1.88. PubMed PMID: WOS:A1981LY62800018.

63. Wilson KA, Chen JC. Amino-acid-sequence of mung bean trypsin-inhibitor and its modified forms appearing during germination. Plant Physiol 1983; 71(2): 341-9. doi: 10.1104/ pp.71.2.341. PubMed PMID: WOS:A1983QD06800022.

64. Lin KF, Liu YN, Hsu STD, Samuel D, Cheng CS, Bonvin AMJJ, et al. Characterization and structural analyses of nonspecific lipid transfer protein 1 from mung bean. Biochemistry 2005; 44(15): 5703-12. doi: 10.1021/Bi047608v. PubMed PMID: ISI:000228425600015; English.

65. Ye XY, Ng TB. Mungin, a novel cyclophilin-like antifungal protein from the mung bean. Biochem Biophys Res Commun 2000; 273(3): 1111-15. doi: 10.1006/bbrc.2000.3067. PubMed PMID: ISI:000088363700055; English.

66. Wang HX, Liu WK, Ng TB, Ooi VEC, Chang ST. Immunomodulatory and antitumor activities of a polysaccharidepeptide complex from a mycelial culture of Tricholoma sp., a local edible mushroom. Life Sci 1995; 57(3): 269-81. doi: 10.1016/0024-3205(95)00270-G.

\section{*Zhu Yi-Shen}

College of Biotechnology and Pharmaceutical Engineering

Nanjing Tech University

Nanjing 211816, China

Email: zhuyish@njtech.edu.cn 